IZA DP No. 4916

A Long-Run View of the University Gender Gap in Australia

Alison L. Booth

Hiau Joo Kee

April 2010 


\title{
A Long-Run View of the University Gender Gap in Australia
}

\author{
Alison L. Booth \\ Australian National University, \\ University of Essex, CEPR and IZA \\ Hiau Joo Kee \\ Australian National University
}

Discussion Paper No. 4916

April 2010

IZA

P.O. Box 7240

53072 Bonn

Germany

Phone: +49-228-3894-0

Fax: +49-228-3894-180

E-mail: iza@iza.org

Any opinions expressed here are those of the author(s) and not those of IZA. Research published in this series may include views on policy, but the institute itself takes no institutional policy positions.

The Institute for the Study of Labor (IZA) in Bonn is a local and virtual international research center and a place of communication between science, politics and business. IZA is an independent nonprofit organization supported by Deutsche Post Foundation. The center is associated with the University of Bonn and offers a stimulating research environment through its international network, workshops and conferences, data service, project support, research visits and doctoral program. IZA engages in (i) original and internationally competitive research in all fields of labor economics, (ii) development of policy concepts, and (iii) dissemination of research results and concepts to the interested public.

IZA Discussion Papers often represent preliminary work and are circulated to encourage discussion. Citation of such a paper should account for its provisional character. A revised version may be available directly from the author. 
IZA Discussion Paper No. 4916

April 2010

\section{ABSTRACT}

\section{A Long-Run View of the University Gender Gap in Australia*}

The first Australian universities were established in the 1850s, well before the introduction of compulsory schooling. However it was not until the twentieth century that growing industrialisation, technological change and the development of the so-called "knowledge industries' fed into an increased demand in Australia for better-educated workers. As the twentieth century progressed, technological change and industrial restructuring saw a shift from brawn to brain. From the middle of the twentieth century, the introduction of mass secondary school education and the expansion of the number of universities widened access. At the same time, subjects offered in higher education increased in scope, and explicit and implicit labour market discrimination began to be eroded. These factors, together with a series of supply-side changes, meant that women were more easily able to shift into investing in the skills in which labour demand was increasing. By 1987, Australian women were more likely than men to be enrolled at university. These aggregate figures disguise considerable heterogeneity across fields of study.

JEL Classification: $\quad$ I23, J1, N3

Keywords: $\quad$ higher education, gender, Australia

Corresponding author:

Alison Booth

Research School of Economics

Australian National University

Canberra ACT 0200

Australia

E-mail: Alison.booth@anu.edu.au

\footnotetext{
* We thank the Editor Martin Shanahan and two anonymous referees for helpful comments. The paper was first prepared for the conference 'Australian Economic History in the Long Run' held at the Australian National University on 26-27 March 2009. We thank participants for their comments and also thank, without implicating, Naomi Elliott from the Australian Bureau of Statistics for her helpful suggestions about the Census data. Part of this research was funded by an ARC Discovery Project Grant. Confidentialised unit record files from the Household, Income and Labour Dynamics in Australia (HILDA) Survey are used in Table 3. We therefore note that the HILDA Project, initiated and funded by the Commonwealth Department of Family and Community Services (FaCS), is managed by the Melbourne Institute of Applied Economic and Social Research (MIAESR) and that the findings and views reported herein are those of the authors and should not be attributed to either FaCS or the MIAESR.
} 


\section{Introduction}

In the vast majority of OECD countries women now have greater enrolment rates in higher education than men (OECD, 2008) and at the same time there has been a secular increase in female labour market participation rates. While the broad factors affecting university enrolment are common across countries, there are interesting differences in timing. However, our goal here is not to provide a cross-country comparison, but to move back in time to explore the Australian developments in higher education that affected the evolution of enrolments. In our paper we chart the growth in the proportion of female enrolments in Australian universities, and focus on demand and supply side factors as potential explanations for these patterns.

The first Australian universities were established in the 1850s, well before the introduction of compulsory schooling. However in Australia it was not until the twentieth century that growing industrialisation, technological change and the development of what Goldin and Katz (2008) term the 'knowledge industries' was to feed into an increased demand for better-educated workers. As the twentieth century progressed, technological change and industrial restructuring saw a shift from brawn to brain. From the mid-twentieth century, access to universities was widened by the introduction of mass secondary-school education and the expansion of the number of universities. This, together with a series of supply-side changes, meant that women were more easily able to shift into the occupations and industries in which labour demand was increasing - white collar work and the service industries.

What were these supply-side changes? They were societal, technical and cultural. One important development was the decline in discrimination against women in the labour market following on from the 1960s civil rights movement. As women experience improved career opportunities, they benefit from a higher return to tertiary education and so invest more. A second is that divorce rates have grown over the last three decades, and investing in a career provides a woman with insurance against marital breakdown and the concomitant income uncertainty. Moreover social custom about women's roles evolved dramatically over the last half century, ${ }^{1}$ and technological breakthroughs in household production have released female time from domestic labour. These trends, coupled with contraception innovations and the wider

\footnotetext{
${ }^{1}$ Of course, social custom and work preferences may be shaped by supply and demand-side factors, as is recognized not only by political economists but also those in charge of government propaganda. See for example the campaigns in various countries to get women out of work after their men folk returned from wars.
} 
availability of abortion, have made it easier for women to delay family formation and enjoy the returns to university education.

\section{The Evolution of Australian Universities}

The two largest colonies, NSW and Victoria, established universities in the 1850s, with a limited range of disciplines. ${ }^{2}$ Further developments in enrolments and curriculum were gradual, partly due to the small population. Moreover, the frontier nature of society meant that it saw little practical advantage in post-primary education, and the workforce was largely engaged in primary industry where academic skills were of less relevance. The lack in Australia of a leisured upper class that might be educated in the universities was a contrast to the situation in England. The strong secular nature of Australian society, together with representation of a number of different religious denominations, discouraged university involvement in the education of clergy, again a contrast with England. The growth of Australian universities was not helped by the fact that educated professionals could be readily obtained through migration from Britain. Furthermore, a university education was not a prerequisite for recruitment into the public service, in contrast to admission into the civil service in Britain. All these factors contributed to the low enrolments in universities in Australia in the early years (Barcan, 1980).

While Australian universities began slowly, they did move relatively quickly to enrol women, who were admitted into Melbourne University from 1879 and into Sydney University from 1881. ${ }^{3}$ This development was preceded in 1871 by the admission of girls to the University Matriculation exams in Victoria in 1871 and to the two Public Examinations in NSW, thereby stimulating the growth, from the 1870s, of colleges for girls with an academic curriculum similar to that in the boys' grammar schools (Barcan, 1980:124).

In the years up to the First World War, educational aims advanced beyond universal literacy. ${ }^{4}$ The educational system was characterised by a distinction between academic and

\footnotetext{
2 The University of Sydney, established in 1850, began lectures in 1852, while the University of Melbourne was set up in 1853 and lectures started in 1855. At Melbourne, there were four fields: classics, mathematics, natural history and moral sciences, while at Sydney there were three: classics, mathematics and chemistry. See Barcan (1980).

${ }^{3}$ Melbourne University, for example, conferred only nine Bachelor degrees in 1878, and the admission of women was a means of facilitating the expansion of undergraduates (Barcan, 1980).

${ }^{4}$ Illiteracy, a crude measure of educational attainment, can be proxied by marriage signatures being signed with a mark. Of the total 1861 population that was married, the proportion signing with a mark was around 31\% of women and 19\% of men. The adult illiteracy rate in 1861 England, using the same measure, was 35\% for women and 25\% for men (Graff, 1979). This comparison lends weight to the argument that nineteenth century immigration to Australia was selective. The comparable figure for Scotland in 1861 was $20-25 \%$ female illiterates and $10-12 \%$ male (Graff, 1979). ${ }^{4}$ In Australia by 1871, illiteracy rates of those married had dropped to $16 \%$ for women and $11 \%$ for men. By the time of Federation in 1901, illiteracy of those married was under 1\% for both men and women, indicating an improvement in education both within Australia and abroad. The proportion illiterate among those
} 
vocational education, with State academic schools providing a route into the professions and vocational schools into trade and industry (Barcan, 1980: 234). While the professions and white collar jobs were growing, primary and manufacturing industry still accounted for the majority of employment at federation, and by 1910-11 accounted for 52\% of the total workforce (Keating, 1973; Withers, Endry and Perry, 1987). Indeed, employment proportions in industries apart from primary and manufacturing were to remain fairly stable for the first half of the twentieth century.

By the time the colonies federated in 1901, Australia's population numbered around 3.788 million people. Of these, $77.2 \%$ were Australian-born and $18 \%$ were born in the UK or Ireland (ABS, 2006). While the Australian colonies were among the first in the world to introduce compulsory schooling for primary-school age children in the second half of the nineteenth century, it was still the case that, by 1901, 7.1\% of the population aged over 5 years could not read (ABS 2006). ${ }^{5}$ By 1911, in spite of the fact that primary school education was mandatory, participation in education was only $92.5 \%$ for children aged $6-11,85.2 \%$ of children aged $12-13$ and $31.2 \%$ of children aged 14-15.

In 1911 only 2,465 Australians - around $0.055 \%$ of the total population of 4.455 million - were receiving educational instruction at a university, as shown in the top panel of Table 1, while around 775,390 (17.4\%) were recorded as receiving any type of educational instruction. Of the 2,465 people attending a university, some 539 (21.9\%) were women. But by 1921, as the bottom panel of Table 1 shows, university attendance and the female proportion had increased. Of the total population of 5.435 million people, $20.4 \%(1,107,690)$ were recorded as receiving educational instruction. There were now 7,252 students attending university, and of these 2,123 (29.3\%) were women.

married remained under $1 \%$ for the entire data series up to 1921. See Australian Bureau of Statistics (ABS) 19011923.

${ }^{5}$ Compulsory primary education was introduced Tasmania in 1868, in 1871 in Western Australia, in 1872 in Victoria, 1875 in SA , in 1880 in NSW, and in 1900 in Queensland. The states varied considerably in the dates at which they introduced free and secular primary education. The 1872 ACT in Victoria and the 1880 Act in NSW were the most ambitious in the sense of aiming to introduce free, compulsory and secular education at the one time. See Barcan (1980: 151), and also Austin (1977). 
Table 1: Place of Education, Census 1911 and 1921

\begin{tabular}{|c|c|c|c|c|c|c|c|c|}
\hline & $\begin{array}{l}\text { State } \\
\text { School }\end{array}$ & $\begin{array}{l}\text { Private } \\
\text { School }\end{array}$ & $\begin{array}{c}\text { Technic } \\
\text { al } \\
\text { School }\end{array}$ & $\begin{array}{c}\text { Univers } \\
\text { ity }\end{array}$ & $\begin{array}{c}\text { At } \\
\text { home }\end{array}$ & $\begin{array}{c}\text { Scholar } \\
\text { but } \\
\text { school } \\
\text { not } \\
\text { stated }\end{array}$ & $\begin{array}{c}\text { Total } \\
\text { Number } \\
\text { receiving } \\
\text { education } \\
\text { (a) }\end{array}$ & $\begin{array}{c}\text { Total } \\
\text { Population } \\
\text { (millions) }\end{array}$ \\
\hline \multicolumn{9}{|l|}{ Census 1911} \\
\hline$\overline{\text { Male - Person }}$ & 298,386 & 70,145 & N/A & 1,926 & 10,450 & 10,293 & 391,200 & 2.31 \\
\hline$-\%$ & 51.7 & 46.4 & N/A & 78.1 & 45.3 & 47.7 & 50.5 & \\
\hline Female - Person & 278,819 & 80,960 & N/A & 539 & 12,593 & 11,279 & 384,190 & 2.14 \\
\hline$-\%$ & 48.3 & 53.6 & N/A & 21.9 & 54.7 & 52.3 & 49.5 & \\
\hline Total & 577,205 & 151,105 & N/A & 2,465 & 23,043 & 21,572 & 775,390 & 4.45 \\
\hline \multicolumn{9}{|l|}{ Census 1921} \\
\hline$\overline{\text { Male - Person }}$ & 395,268 & 88,800 & 17,868 & 5,129 & 14,141 & 42,346 & 563,552 & 2.77 \\
\hline$-\%$ & 51.5 & 45.8 & 71.5 & 70.7 & 46.0 & 50.3 & 50.9 & \\
\hline Female - Person & 371,573 & 104,974 & 7,116 & 2,123 & 16,571 & 41,781 & 544,138 & 2.68 \\
\hline$-\%$ & 48.5 & 54.2 & 28.5 & 29.3 & 54.0 & 49.7 & 49.1 & \\
\hline Total & 766,841 & 193,774 & 24,984 & 7,252 & 30,712 & 84,127 & $1,107,690$ & 5.45 \\
\hline
\end{tabular}

Note: (a) Number calculated by adding total number of persons receiving education instructions from state school, private school, technical school, university, at home and scholar but not stated.

Source: ABS 1911, 1921.

The emphasis on academic secondary education for a limited fraction of children was slow to change. Although the end of the Great Depression meant that schools could begin to recover from their neglect during this period of great financial hardship, by 1938 the proportion of children proceeding beyond primary school was still low, especially in state schools. Thus in 1938, in NSW around 20\% of children at state schools were in post-primary courses, compared with 15\% in Victoria, 3\% in Queensland, 11\% in SA and Tasmania, and 14\% in WA (Barcan, 1980: 267). However by the start of the Second World War, not only was the Australian economy recovering and industrialisation growing, but there was also a new interest in the ideas of progressive education. Postwar, this was to lead to the adoption of mass secondary education, which was ultimately to feed through into an expansion of the university sector.

University enrolments grew slowly from federation in 1901 until the Second World War. The war was associated with an expansion of government intervention in university and technical education, as well as a growing interest in bettering the social order including access to education. The Commonwealth Government became involved in postsecondary education, while after the war State governments were to make secondary education more accessible to those of lower academic ability. Commonwealth involvement in universities was to lead to considerable changes in access and financing, as we shall see. 
Figure 1: Total university enrolments, 1906-1972

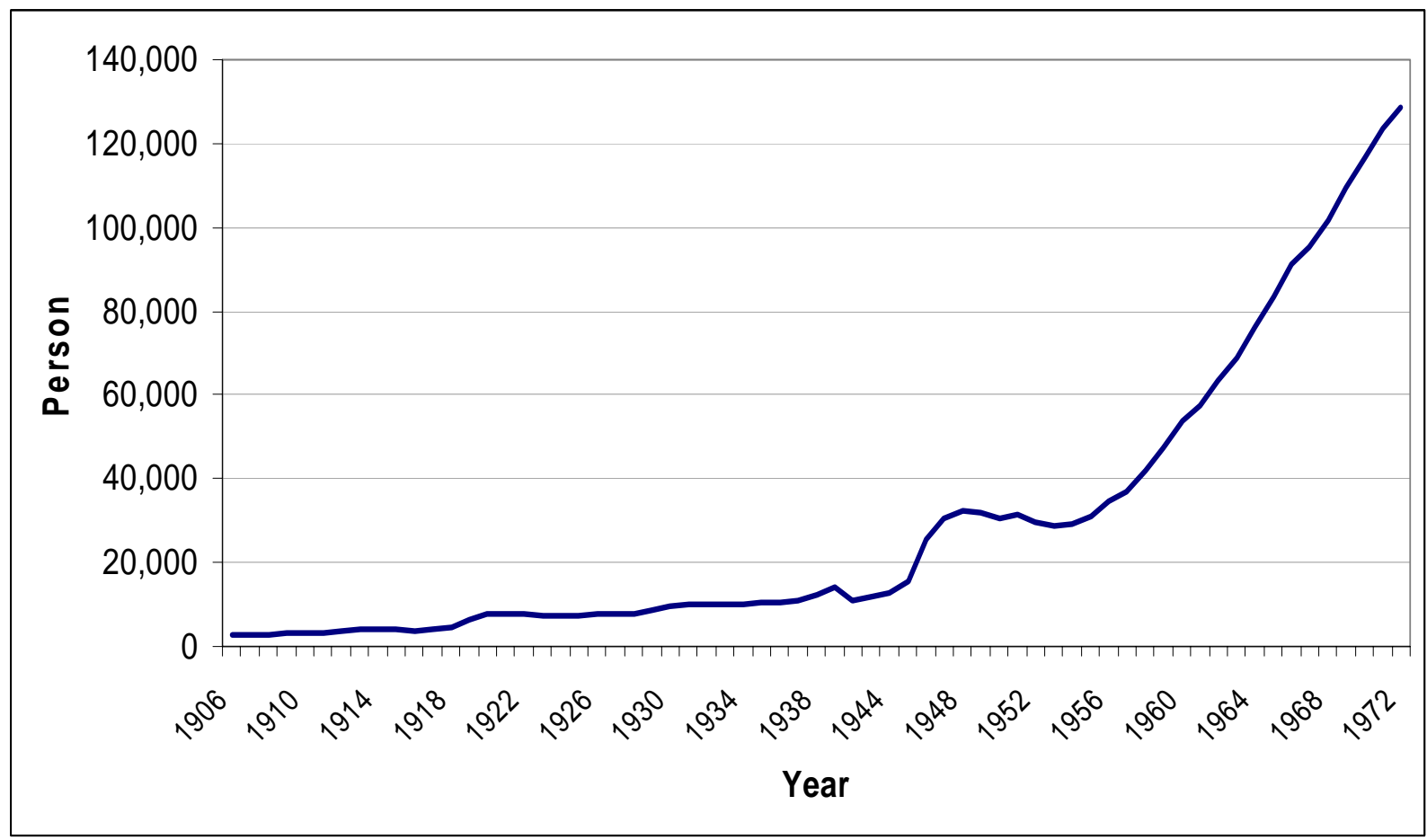

Source: ABS 1906-1974.

Figure 1 shows the trend in the total numbers of students enrolled at universities from 1906 to 1972. The immediate post-war jump in enrolments is clearly visible. After this there was a plateau until towards the late 1950s, when enrolments began to grow rapidly. That academic disciplines were becoming increasingly specialised, as highlighted for the US in Goldin and Katz (2008), heralded a division of labour within higher education. After the Second World War, universities established new courses, faculties and chairs (Barcan, 1980). New universities were also set up, including the only Australian university to be established by an act of the Federal Parliament - the Australian National University. ${ }^{6}$ Universities continued to expand in number, especially from the late 1960s. At the same time Colleges of Advanced Education (CAEs) were created, and these were in time to become degree-awarding institutions. From the

\footnotetext{
${ }^{6}$ The Australian National University was established by the Australian National University Act 1946-7 as part of the postwar nation-building exercise. It was set up specifically as a research-based university, and enrolled only postgraduate students until taking over the Canberra University College in 1960, which then enabled it to provide undergraduate education. Other universities were also established, including the NSW University of Technology, later to become the University of NSW and the University of New England which in 1954 became independent from its former role as a Sydney University College.
} 
late 1980s, the CAEs achieved university status and the Commonwealth government initiated a new push for expansion of access to universities.

In summary, the postwar period represented a deepening of academic specialisation within universities, a growth in the number of disciplines, and an expansion of the university sector. The introduction of mass secondary education facilitated a subsequent increase in higher education enrolments. At the same time, white-collar occupations were expanding and the population was growing. Industrial restructuring, technological change and the growth of knowledge industries saw an increase in demand for better-educated workers. The civil rights movement of the 1960s and the innovation in contraceptive technology were to see a dramatic change in female expectations of labour force participation and their choice of occupation. These changes were to incline more women towards making an investment in university education.

In the pages that follow, we shall explore in detail the evolution of the gender gap in higher education from 1939 onwards. While it was impossible to obtain the gender breakdown for the entire period for which published enrolment statistics are available, we were able to obtain these data for latter part of the enrolment data series, from 1939 onwards.

\section{University Enrolments by Gender 1939 to 1972}

The data used in this section were obtained from various ABS year books, as will be explained below. Table 2 shows numbers of students enrolled at universities over the period 1939-1972, and the proportion of enrolments by gender. The final column gives the total population of Australia. The first two rows of the table repeat the information from the 1911 and 1931 censuses, for ease of comparison.

After 1921, the earliest gender breakdown of students enrolled at universities is for 1939, when the total population was almost 7 million. Of these, only 14,236 were enrolled at universities. ${ }^{7}$ Fewer than 28\% $(3,942)$ of those enrolled at universities were female. (This proportion is less than in the 1921 Census data. Note that the data in Table 2 come from figures released by the statistical officers of the Australian Universities and subsequently published in the ABS Year Books.)

Inspection of Table 2 reveals that the absolute number of male enrolments dropped from around 10,000 at the outbreak of the Second World War, to around 7,000 during the war years.

\footnotetext{
${ }^{7}$ This compares with a total of 1556 students at Australian universities in 1899 (Barcan, 1980).
} 
The number of women enrolled at universities - nearly 4,000 in 1939 - fell in 1942 but grew from 1943. The net result of these changes was that the female proportion of university enrolments increased to 39\% by 1944 .

Table 2: Students enrolled at universities, 1939-1972

\begin{tabular}{|c|c|c|c|c|c|c|}
\hline & \multicolumn{2}{|l|}{ Male } & \multicolumn{2}{|l|}{ Female } & \multirow{2}{*}{$\begin{array}{l}\text { Total } \\
\text { Person }\end{array}$} & \multirow{2}{*}{$\begin{array}{l}\text { Total } \\
\text { Population } \\
\text { (million) }\end{array}$} \\
\hline & Person & $\%$ & Person & $\%$ & & \\
\hline 1911* & 1,926 & 78.1 & 539 & 21.9 & 2,465 & 4.45 \\
\hline $1921 *$ & 5,129 & 70.7 & 2,123 & 29.3 & 7,252 & 5.45 \\
\hline 1939 & 10,294 & 72.3 & 3,942 & 27.7 & 14,236 & 6.97 \\
\hline 1942 & 7,025 & 65.3 & 3,736 & 34.7 & 10,761 & 7.18 \\
\hline 1943 & 7,201 & 61.7 & 4,474 & 38.3 & 11,675 & 7.24 \\
\hline 1944 & 7,876 & 60.7 & 5,090 & 39.3 & 12,966 & 7.31 \\
\hline $1945^{t}$ & 10,622 & 57.2 & 4,964 & 35.6 & 15,586 & 7.39 \\
\hline 1946 & 19,346 & 75.6 & 6,239 & 24.4 & 25,585 & 7.47 \\
\hline 1947 & 23,939 & 78.5 & 6,538 & 21.5 & 30,477 & 7.58 \\
\hline 1948 & 25,540 & 78.7 & 6,913 & 21.3 & 32,453 & 7.71 \\
\hline $1949^{t}$ & 24,942 & 77.4 & 6,811 & 21.4 & 31,753 & 7.91 \\
\hline 1950 & 24,023 & 78.4 & 6,607 & 21.6 & 30,630 & 8.18 \\
\hline 1951 & 25,349 & 80.0 & 6,322 & 20.0 & 31,671 & 8.42 \\
\hline 1952 & 23,798 & 80.3 & 5,843 & 19.7 & 29,641 & 8.64 \\
\hline 1953 & 22,794 & 79.2 & 5,998 & 20.8 & 28,792 & 8.82 \\
\hline 1954 & 23,113 & 78.7 & 6,261 & 21.3 & 29,374 & 8.99 \\
\hline 1955 & 24,042 & 78.1 & 6,750 & 21.9 & 30,792 & 9.20 \\
\hline 1956 & 26,872 & 77.9 & 7,608 & 22.1 & 34,480 & 9.43 \\
\hline 1957 & 28,816 & 78.1 & 8,087 & 21.9 & 36,903 & 9.64 \\
\hline 1958 & 32,642 & 78.0 & 9,223 & 22.0 & 41,865 & 9.84 \\
\hline 1959 & 36,830 & 77.4 & 10,735 & 22.6 & 47,565 & 10.06 \\
\hline 1960 & 41,385 & 77.0 & 12,395 & 23.0 & 53,780 & 10.28 \\
\hline 1961 & 44,264 & 76.8 & 13,408 & 23.2 & 57,672 & 10.55 \\
\hline 1962 & 48,007 & 75.8 & 15,310 & 24.2 & 63,317 & 10.74 \\
\hline 1963 & 51,894 & 75.1 & 17,180 & 24.9 & 69,074 & 10.95 \\
\hline 1964 & 56,424 & 74.1 & 19,764 & 25.9 & 76,188 & 11.17 \\
\hline 1965 & 61,285 & 73.6 & 22,035 & 26.4 & 83,320 & 11.39 \\
\hline 1966 & 66,303 & 72.6 & 24,969 & 27.4 & 91,272 & 11.60 \\
\hline 1967 & 68,979 & 72.3 & 26,401 & 27.7 & 95,380 & 11.80 \\
\hline 1968 & 72,470 & 71.4 & 29,067 & 28.6 & 101,537 & 12.01 \\
\hline 1969 & 77,822 & 71.0 & 31,840 & 29.0 & 109,662 & 12.26 \\
\hline 1970 & 81,847 & 70.1 & 34,931 & 29.9 & 116,778 & 12.51 \\
\hline 1971 & 84,800 & 68.5 & 38,976 & 31.5 & 123,776 & 13.07 \\
\hline 1972 & 86,540 & 67.3 & 42,128 & 32.7 & 128,668 & 13.30 \\
\hline
\end{tabular}

Source: ABS 1911, 1921, 1941-1974.

Notes: * Census data in 1911 and 1921.

Data from 1939 and after were extracted from the Australian Year Book.

${ }^{\mathrm{t}}$ Interpolated data are presented here, as the gender break down is not available. 
Once Japan entered the war in December 1941, manpower and production problems became of paramount importance. The Commonwealth government stepped in to control enrolments under its National Security regulations and later its manpower regulations (Barcan, 1980: 288). Thus enrolments fell to 10,761 in 1942. In the same year, a Universities' Commission was established, which classified certain disciplines as exempt from military service (these were medicine, science, engineering, dentistry, veterinary science and agriculture). To facilitate student access to these reserved faculties, the Commonwealth Financial Assistance Scheme was introduced at the start of 1943. This was to be retained and extended to all faculties once the war ended.

The Commonwealth Reconstruction Training Scheme was the second form of Commonwealth government intervention in universities. According to Barcan (1980: p288), 'By 1947, 12,401 students were receiving university training under CRTS, two-thirds of them fulltime. Over half of the 18,935 full-time university students were receiving a living allowance from the Commonwealth government, either as Reconstruction Training students, or as civilian Financial Assistance students. This was a remarkable social change.’

The 1944 Commonwealth Reconstruction Training Scheme boosted post-war enrolments of men more than women, because the gender composition of the services in World War II was more male. ${ }^{8}$ After the end of the war, the female proportion of university enrolments fell to $24 \%$ in 1946 and declined steadily thereafter until 1952, when just under one fifth of university enrolments were female. It can be seen that enrolments remained at around one fifth female until the early 1960s when female enrolments began to rise. ${ }^{9}$ Figure 2 illustrates graphically the same data.

\footnotetext{
${ }^{8}$ The Commonwealth Reconstruction Training Scheme (CRTS), introduced in March 1944, provided educational and vocational training to those serving in Australia's armed services during World War II (National Archives). Since the gender composition of the services was overwhelmingly male, this would have boosted enrolments of men more than women. The last date for acceptance of applications was 30 June 1950 and by the middle of 1951 over 300,000 people had been accepted by the Scheme. Eligibility was a minimum of six months' service and an honourable discharge. Full-time participants had tuition and other fees paid, and they also received living allowances. See National Archives of Australia, Fact Sheet 178. CRTS Administrative Records, http://www.naa.gov.au/about-us/publications/fact-sheets/fs178.aspx.

${ }^{9}$ We were unable to find published statistics showing the proportion of the total population in particular age groups enrolled at university. Thus we do not know the extent to which the trend growth in numbers enrolled is due to increasing population or to increasing proportion of relevant cohort enrolling at university. The earliest enrolment information with an age breakdown is since 1980.
} 
The Commonwealth Scholarship Scheme also began not long after the war. A referendum in 1949 approved amending the constitution to allow the Commonwealth in peacetime formal powers to provide direct financial support to students. At the end of 1949, the Chifley Government approved three thousand competitively allocated university scholarships. The Menzies Government legislated this as the Commonwealth Scholarship Scheme, which began operation in 1951 (Hastings, 2008). The Commonwealth Scholarships scheme and the associated bursary or living allowances would in principle have reduced the cost of acquiring higher education for men and women alike.

Figure 2: Proportion of females enrolled at universities, selected years from 1911-1972

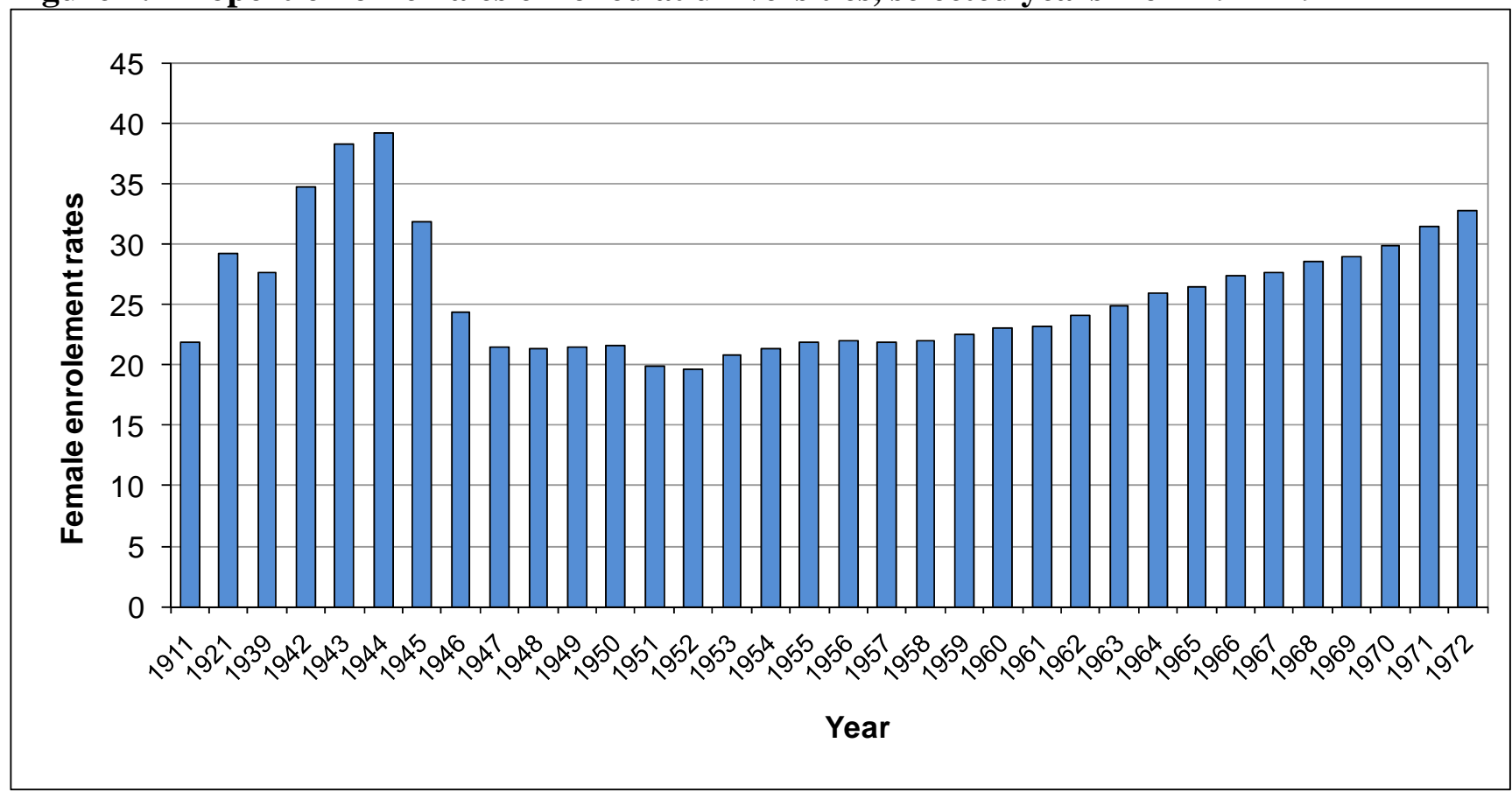

Source: see notes for Table 2.

Australia's involvement in the Vietnam War was also likely to have affected enrolments, although the mechanism was very different to that described above. The Vietnam War was unpopular, especially amongst the young and, in order to increase personnel in the army, conscription was introduced. For the generation of men keen to defer service during Australia’s involvement in the Vietnam War, higher education offered a way out. ${ }^{10}$ After call-up it was

\footnotetext{
10 The Vietnam National Service Scheme, based on a birthday ballot of 20-year-old men, ran from November 1964 to December 1972 (see Australian War Memorial web-based encyclopedia). Those young men chosen by this ballot were called up for two years' continuous full-time service in the Regular Army Supplement, followed by three years' part-time service in the Regular Army Reserve. The scheme was designed to create army strength of 40,000 full-time soldiers.
} 
possible for young men to defer service if they were enrolled in higher education courses. In 1963 just under 52,000 men enrolled at university. By 1972, the end of the ballot procedure, around 86,000 men were enrolled. However, for women over the same period, the increase was from just over 17,000 to around 42,000. The proportion female grew from around 25\% in 1963 to around 33\% in 1972. It is impossible, with our data, to establish if there might have been a larger increase in the female proportion had there not been male conscription for the Vietnam War coupled with the educational 'op-out'.

\section{Data Issues, or Why We Can't Use the Census CURF Files}

The Census data are available from 1981 to 2006 in the format of Confidentialised Unit Record File (CURF) from the ABS. To compare the historical movements in education attainment between males and females, we would ideally want to use the various Census CURF files to calculate average higher educational attainment by gender for each birth cohort. However, there are a number of problems that make it near-impossible to pursue this avenue of research. For a start, our analysis of these data showed that the proportion of people with a university education increased from 1981 to 2006 for all birth cohorts observed in the data. There are a number of possible reasons for this and it proved impossible to distinguish amongst them. First there were classification changes and second, there was a general trend towards mature-age university education. The classification of "undergraduate degree” has changed several times over the period 1981 to 2006. For example, nursing qualification moved from being hospital-based to university-based for registered nurses. Individuals (mainly females) were classified as having a certificate under the old system and this is inconsistent with the new classification. Another profession affected by the change in classification was teaching. Moreover, over time, there has been a significant increase in the proportion of the population obtaining higher educational qualifications at a later stage of their life cycle and it proved impossible to distinguish this from classificational changes. Mature age students are especially common among females. However, Appendix Table A.1 shows that, for both men and women, numbers enrolled in courses are greater for those 35-64 years than for the 25-34 age-group. 
Given that the educational attainment of any birth-cohort - even those aged 35 plus - is changing over time, we preferred to use enrolment data from the universities to construct our time-series diagrams throughout this section. ${ }^{11}$ This is reported in the next section.

\section{A Longer Window: University Enrolments by Gender 1943 to 2007}

Next we present a longer data series obtained from a different data source, selected series published in Higher Education Students Time Series Tables, Department of Education, Training and Youth Affairs (2000). As this series does not match precisely with the ABS data in Table 2, we do not attempt to splice the two data series. Figure 3 shows the proportion of females in university enrolment from 1943 to 2007. It includes both overseas and domestic students over the entire period. Statistics from 1974 to 1989 include University and Colleges of Advanced Education (CAEs) and are based on figures from the Commonwealth Bureau of Census and Statistics (CBCS), Commonwealth Tertiary Education Commission (CTEC), Department of Employment, Education and Training (DEET) statistics. Comparable data for CAEs for years prior to 1974 are not publicly available.

Using these different data, Figure 3 supports the trends shown in Table 2. (There is no overseas/domestic student breakdown prior to 1988, perhaps because overseas students were relatively rare.) Notice again the steady increase from a low of one-fifth female in 1952 up to the mid-1970s when there was a big jump, no doubt due at least in part to the inclusion from that time of CAE enrolments, as well as to the abolition of fees in 1974 by the Whitlam government. However unemployment could also have played a role, since it grew steadily from about this time up to around $10 \%$ by the early 1980s (see Appendix Figure A.1), a peak it was to exceed in the early 1990s. Second, Figure 3 reveals that by 1987 - two years before the removal of the binary divide and the introduction of the Higher Education Contribution Scheme (HECS) there was gender parity. By 2007 the share of women had grown to around 55\%.

\footnotetext{
${ }^{11}$ We were unable to consistently isolate nurses and teachers for all the censuses. While we experimented with using the variable "field of study", this was problematic as the ABS changes its coding for this variable almost every census year. We also tried using occupation but the census data is coded into broad groups making it impossible to isolate teachers and nurses, who are grouped with different professionals depending on which census we are looking at. Hence we chose not to construct an historical time series using census birth cohorts.
} 
Figure 3: University Attendance by Gender, 1943-2007 (both domestic and foreign students)

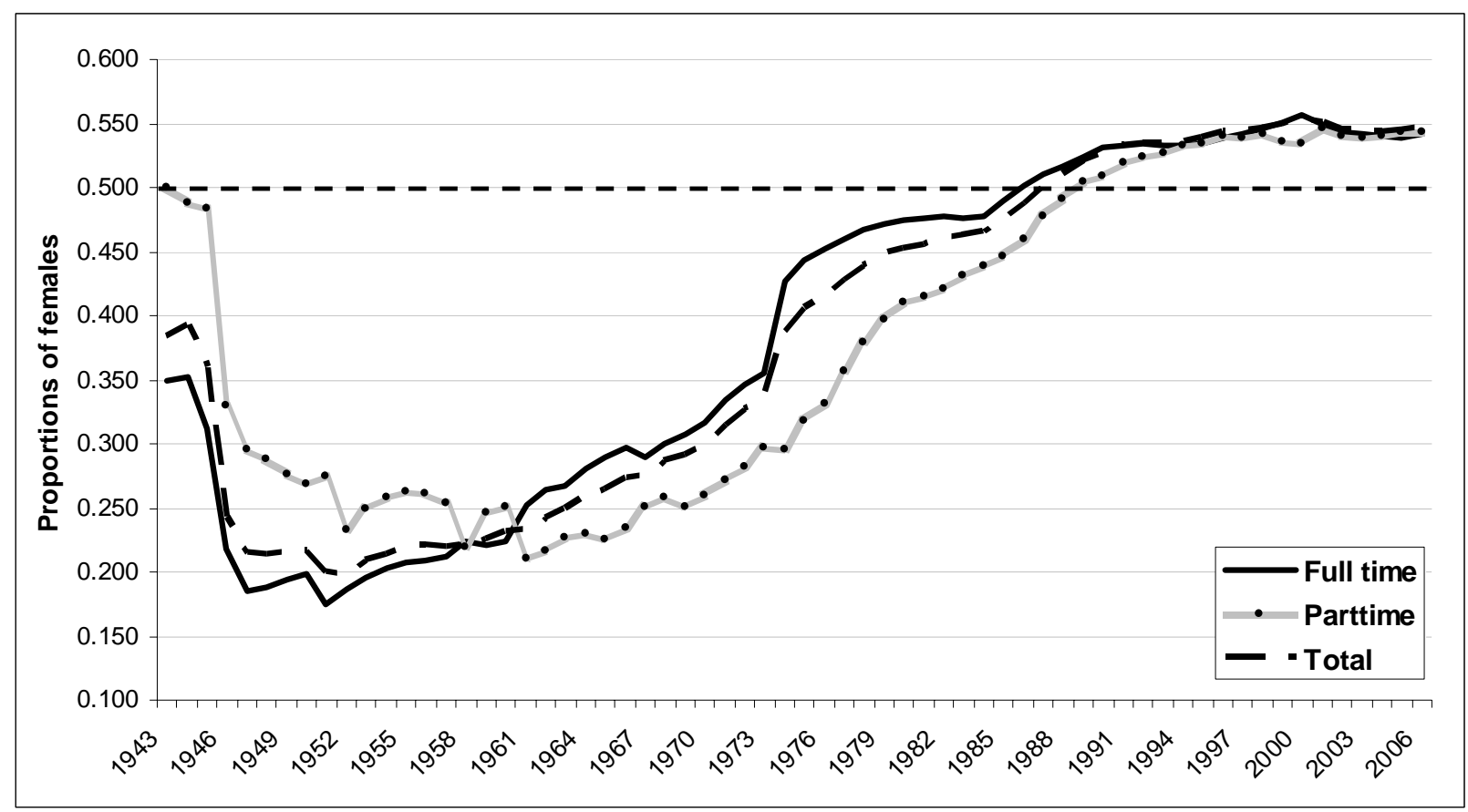

Source: This graph is derived using selected series published in DETYA (2000). Figures after 2000 were obtained using online published data from DEEWR (2001-2007).

Since it is possible that the inflow of overseas students into the Australian universities alters the pattern of gender gaps in university enrolments, we searched for a disaggregated data source. The earliest publicly available university enrolment data, disaggregating by both gender and domestic/overseas status, start in 1988, and are from DETYA (2000) and DEEWR (20012007). When we investigated these data, we found that the gender gaps in university attendance are broadly comparable between domestic and overseas students over the period from 1988 to 2007. However, among domestic students, the gender gap favouring women seems to grow slightly faster from 2001. 


\section{Figure 4: University students by gender and age groups} (both domestic and foreign students)

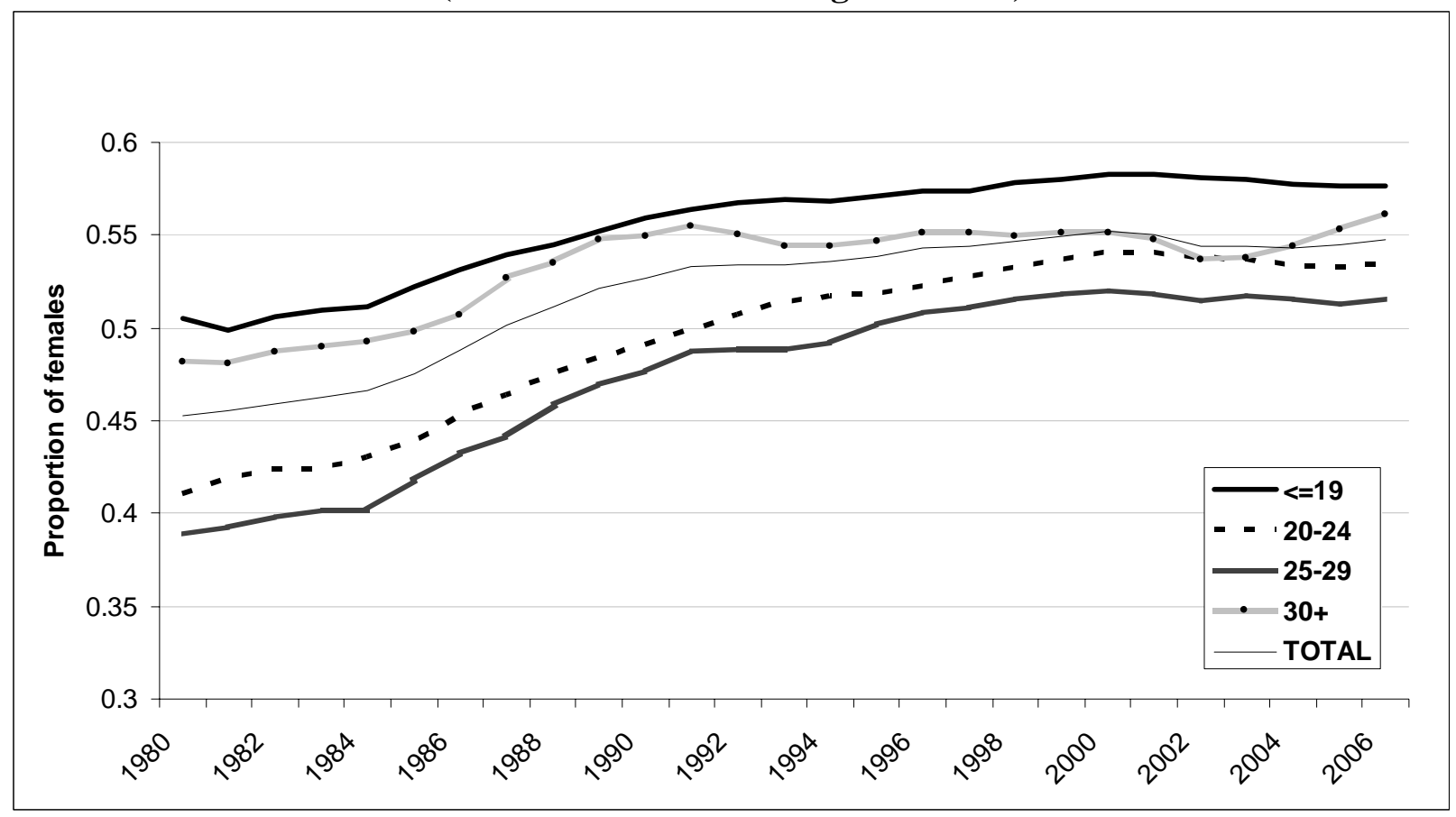

Source: This graph is derived using selected series published in DETYA (2000). Figures after 2000 were obtained using online published data from DEEWR (2001-2007).

Figure 4 illustrates the university gender gap for various age groups. Amongst the more mature students, those at least 30 years of age, gender parity occurred in the mid-1980s, perhaps reflecting women being more likely than men to return to education or to prolong it. Not long after HECS was introduced in 1989, this trend flattened out for this age group. In contrast, gender parity for the relatively young - those aged less than 20 years - occurred far earlier than 1987 (the gender parity date for all age groups), suggesting perhaps that men are more likely to take gap years or that women are more likely to drop out after 20.

\section{What Explains the Gender Gap in University Enrolments 1939-2007?}

\section{i. Deviations around trends; the role of war}

An event such as war is likely to affect men's university enrolments differently to women's. We have seen that, while the female proportion of university enrolments increased to $38 \%$ by 1943 , the absolute number of university students fell during the war. Afterwards, enrolments of men were boosted by the Commonwealth Reconstruction Training Scheme. The female proportion of university enrolments fell to 24\% in 1946 and declined steadily thereafter until 1952, when just 
under one fifth of university enrolments were female, and enrolments remained at around one fifth female until the early 1960s when they began to become more female.

Did the Vietnam war have a similar effect? Australia sent far fewer personnel to this war than to the two world wars, and the mechanisms affecting educational choices were different. While higher education was clearly a means for conscripted young men of avoiding service, the statistics do not allow us to establish if the effect on enrolments was large. Moreover other factors were also propelling the nation forward and affecting the behaviour of young women and men.

\section{ii. Long-run trends}

As a country gets richer, it educates males and females more. Twentieth century technological breakthroughs in household technology and in contraception removed constraints to female and male choice. Growing industrialisation, technological change and the development of the 'knowledge industries' fed into an increased demand for better-educated workers. A technological shift from brawn to brain increased the demand for skilled labour and raised relative skilled wages. Moreover labour demand continued to increase in white collar occupations and the service industries.

From the middle of the twentieth century, access to Australian universities was widened by the introduction of mass secondary school education and the expansion of the number of universities to a total of 39. The curriculum also expanded, as academic specialisation increased. Women were now more easily able to postpone family formation and thus found it worthwhile to invest in higher education in its diverse forms. Gender stereotypes became eroded. The civil rights movement of the 1960s demanded - and succeeded in obtaining - equal rights for women and blacks, raising awareness of discrimination. In the labour market explicit discrimination against women was slowly reduced. ${ }^{12}$ The marriage bar was removed by State and Commonwealth governments.

As women experienced improved career opportunities, they enjoyed a higher return to tertiary education and so invested more. At the same time successive governments, reflecting

12 In 1969 the Commonwealth Conciliation and Arbitration Commission's equal pay for equal work decision established an important principle affecting $18 \%$ of women workers, mostly teachers and nurses. A second Federal case in 1972 established the principle of equal pay for work of equal value. This was extended through all awards from 1972 and eventually put an end to separate male and female rates in awards. The gender gap was reduced by 19\% between 1972 and 1977. It was not until 1984 that the Sex Discrimination Act 1984 was passed by the Federal Parliament. See the Equal Opportunities website of the Australian government for more details. 
the evolving preferences of the electorate, passed legislation allowing abortion on demand and divorce without blame. The removal of the marriage bar increased the incentives for women to invest in education. ${ }^{13}$ Innovations in the funding of higher education widened access to children from lower income families, which may have assisted women more than men.

All of these factors are likely to have accounted for the trend increase in female-to-male higher education enrolment rates since the early 1960s. We now discuss some of those factors in more detail.

\section{Labour market opportunities}

Women born and raised in an era when female workforce participation rates and female wages were relatively low might have expected that they would not themselves be participating in the workforce for long and therefore that investment in higher education would bring insufficient returns to cover the costs (Appendix Figures A.2 and A.3 show male and female participation rates and real wages plotted over the period 1978 to 2008). For example, those women born in 1962 would - when making the staying-on-at school decision at age 15 or 16 - have expected participation rates of around 50\%. Those born two decades later would have expected much higher participation probabilities, heading towards $70 \%$, and therefore would have wanted to invest more. $^{14}$

Gender wage gaps, although still present, have been much reduced over the past few decades. For much of the twentieth century, industrial tribunals in Australia enforced a policy of wage discrimination against female workers (Borland, 1999; Eastough and Miller, 2004). When doing the same work as men, women were paid a wage equal to that of men, to prevent men from being replaced by cheaper female labour. This pay parity might have encouraged women to invest in education, though it should be remembered that other explicit forms of discrimination (such as the marriage bar) worked against this. However, when female workers were employed alongside other women, they were paid a wage between 54 and 60 per cent of

13 The Commonwealth marriage bar in the Australian Public was not removed until 1966 (see Sawer, 1997). Marriage bars were a common practice restricting married women from employment in many professions, especially teaching and clerical jobs such as in government service. Since marriage bars did not apply to employment in lower paid jobs but did apply to better paid jobs, they reduced the incentive for women to invest in education.

\footnotetext{
${ }^{14}$ We are of course considering only averages here. Some women would have wanted to go to university regardless of average participation probabilities; for example those women who did not wish to marry, those who were very bright, and those who viewed - or whose families might have viewed - university as a place to meet potential marriage partners.
} 
the male rate (Short, 1986). Thus occupational segregation tended to institutionalize gender pay gaps. And gender pay gaps in their turn could discourage women from investing in higher education.

However in 1969, the Equal Pay Case for the first time introduced the concept of equal pay for equal work (Borland, 1999; Eastough and Miller, 2004). Studies of the gender wage gap in Australia show that the Equal Pay Case contributed to an improvement in the relative pay of women (Borland, 1999) with the result that the gender wage gap in Australia is now less than half that in the United States and is amongst the lowest in the OECD (Eastough and Miller, 2004).

Using data from the Household, Income and Labour Dynamics in Australia (HILDA) Survey for the period 2001-6, Baron and Cobb-Clark (2008) chart the extent of occupational segregation, measured by the difference in the proportion of men and women working in specific occupations. They find that it is higher in the private than the public sector. However they find that there is a positive effect of women's occupational position on their relative wages despite a relatively high degree of persistent occupational segregation, in contrast to many other countries.

In sum, growing expectations of workforce participation and a reduction in the gender pay gap are likely to have encouraged women to invest more in higher education. In addition, as the economy has continued to restructure, labour demand has increased in white-collar occupations and the service industries in which women have been largely employed, providing further incentives to invest. By 2007, the agricultural sector accounted for just 3.3\% of the workforce, mining employed 1.3\%, manufacturing 9.9\%; the electricity, gas, water and waste services, and construction industries accounted for $10 \%$, and the remaining industries accounted for $75.5 \%$. (The last group includes wholesale trade; retail trade; accommodation, cafes and restaurants; transport and storage; communication services; finance and insurance; property and business services; government administration and defence; education; health and community services; cultural and recreational services; and personal and other services.)

\section{Demographic changes}

While the median age at first marriage declined in the 30 years after World War II, it increased thereafter, as Figure 5 shows. From 1974, the median age at first marriage of bridegrooms and brides began to increase, and by 1995 it was four years above that for 1974. This may have been caused by more opportunities to enter higher education and delay family formation, as well as 
the greater availability of abortion, the widespread use of the oral contraceptive from 1961 and the rising unemployment levels of the 1970s (Carmichael, 1995). Later first marriage and family formation raises the anticipated period during which the returns to any educational investment could be amortised, further encouraging investment.

\section{Figure 5: Median Age of Bridegrooms and Brides at First Marriage}

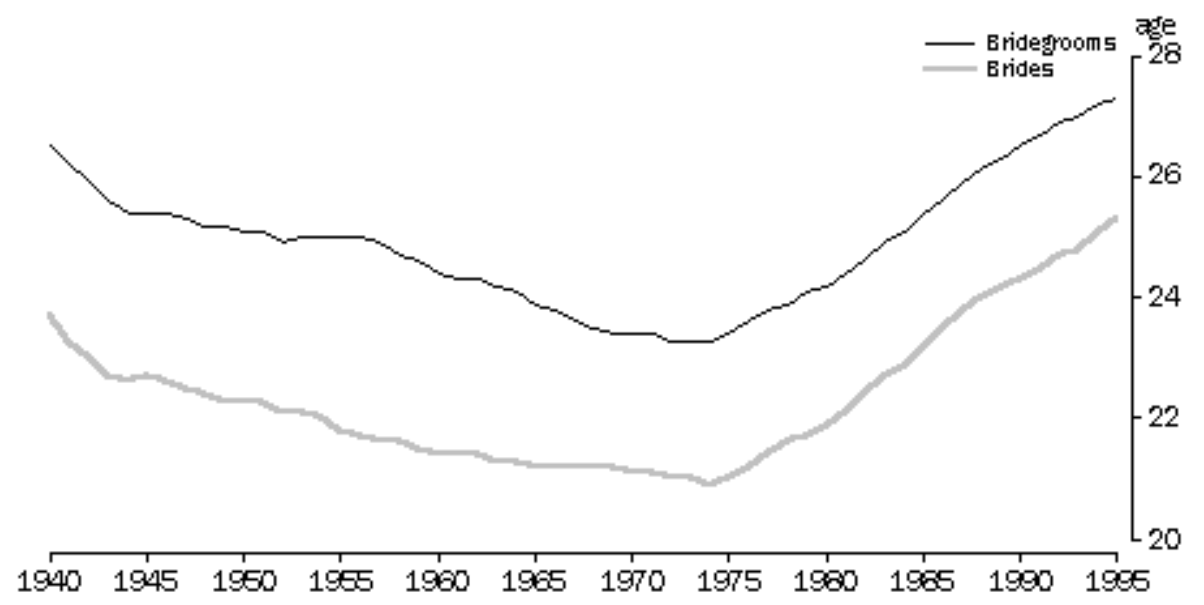

Source: ABS 1997.

The new oral contraception of 1961 and the feminist revolution, together with the wider availability of abortion, made it much easier for women to make choices about their own lives unconstrained by gender stereotyping and to delay formation of families until after they had established careers if that was their choice. Thus median age at first birth (only for first nuptial confinement) increased from 23 years in 1966 to 30.5 years in 2006 - see Appendix Figures A.4 and A.5. ${ }^{15}$

At the same time, cohabitation was becoming more widely accepted. The proportion of Australians who cohabit prior to marriage has grown rapidly from around 5\% in the 1960s to over 70\% currently (Headey, Warren, and Harding, 2006.). In addition, affiliation to a religion

\footnotetext{
${ }^{15}$ The proportion of first marriages involving women marrying younger men increased from $11 \%$ in 1974 to $20 \%$ by 1995, which may have happened due to "relaxation of pressures to conform to previous patterns" (ABS, 1997). Coles and Francesconi (2007) document evidence of changing matching behavior in the U.S. They find a growing proportion of marriages where successful women marry substantially younger men. Such matches are typically characterised by the woman not only being university educated and professionally qualified, but also better educated and in a better occupational class than her male partner.
} 
was reducing, ${ }^{16}$ and people were becoming more willing to stay unpartnered. Moreover, "it is not simply the case that people were marrying later because they were cohabiting as an alternative to marriage: people were also avoiding unions of either type more than they previously had done.” (Carmichael, 1990)

Divorce rates were also increasing over the latter half of the twentieth century. Women and men could no longer expect their first marriage to last and therefore women might consider making educational investments to insure against the risk of income loss. In other words, forward-looking women might have invested in higher education as a means of hedging against the risk of potentially losing their partner's income and being themselves responsible for the maintenance of their children. Of course education and divorce might be endogenous - highly educated women have greater outside opportunities - educated salary - and hence may be less likely to put up with recalcitrant spouses. The crude divorce rate provides a measure of divorce in relation to the total population, and is calculated as the number of divorces granted during a calendar year per 1,000 estimated resident population at 30 June. It is charted in Figure 6 (see left-hand vertical axis), while the number of divorces is also indicated (see right-hand vertical axis).

Figure 6 shows that divorce in Australia was relatively rare until the second half of the twentieth century. While 1947 saw a number of divorces, probably reflecting "hasty wartime marriages and the disruptive effects of the war on marriage” (Weston and Qu, 2006), it was not until the 1960s that the divorce rate began to rise again, peaking with the introduction of the 1975 Family Law Act (4.6 divorces per 1,000 resident population), when easier divorce meant that long-term separations could be legalised. ${ }^{17}$ Since then the crude divorce rate has ranged between 2.3 and 3.0, with a trough occurring in the mid-1980s and a recent decline from 2.7 in 2003 to 2.3 in 2007 (ABS 2007b).

\footnotetext{
${ }^{16}$ The proportion of Australians reporting an affiliation to a religion remained relatively stable from 1933 until 1971 , at slightly less than $90 \%$. This fell to $80 \%$ in 1976, then slowly declined to $73 \%$ in 2001 (ABS, 2004).

${ }^{17}$ The Family Law Act 1975 stipulated only one ground for divorce - "irretrievable breakdown" -measured by a minimum of 12 months separation.
} 
Figure 6: Crude divorce rate and number of divorces, 1901-2005

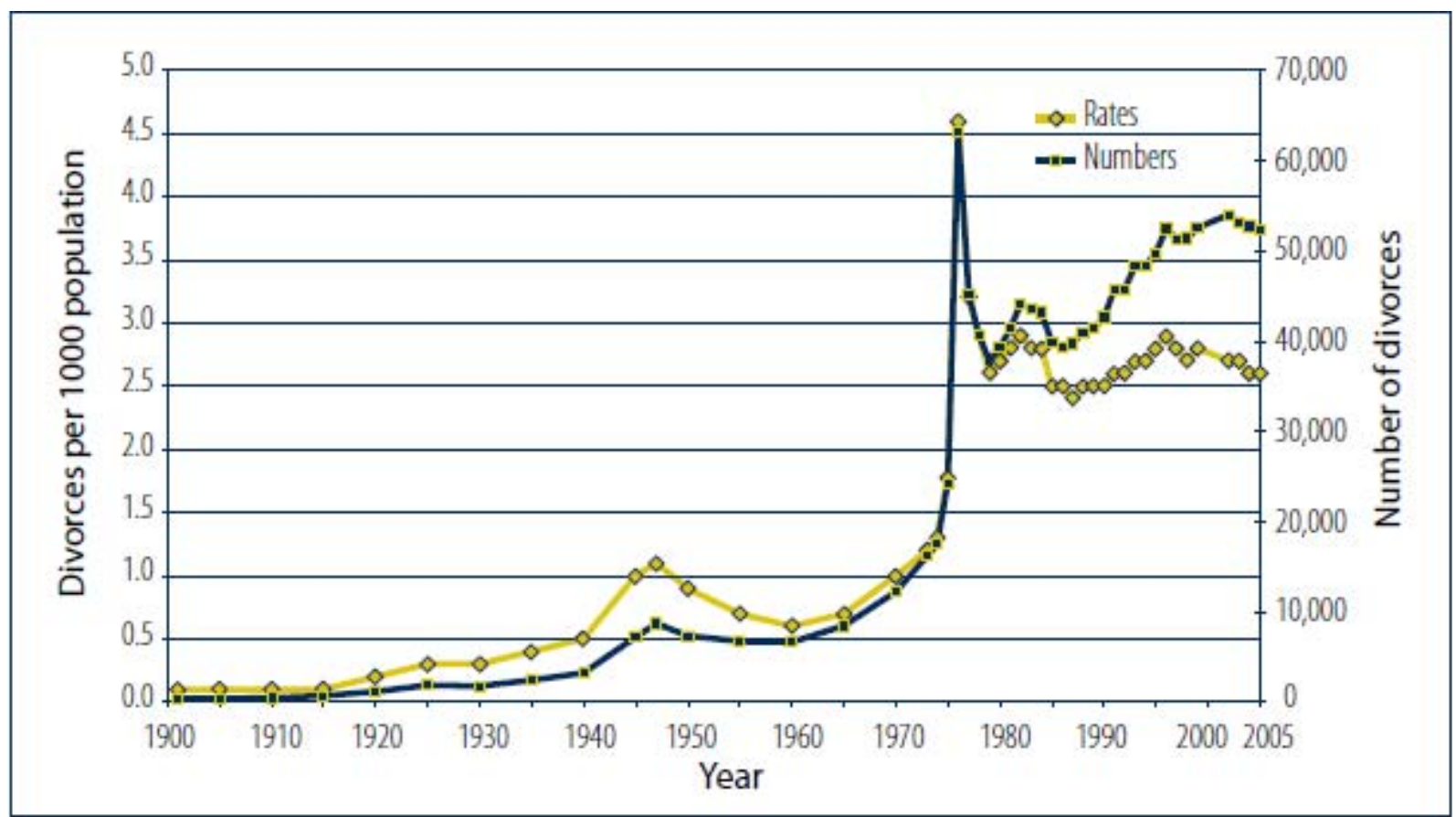

Source: Weston and Qu, 2006.

\section{Changes in financing arrangements.}

In many households, for much of the twentieth century, gender-stereotyping was likely to operate. Hence the introduction of financing inducements might have been particularly attractive for women whose families were unsupportive of investment in higher education. Moreover, their foregone uneducated earnings were lower (female unskilled wages lower than male). ${ }^{18}$

Table 3 shows that, even in 2005, low income households exhibit significantly more gender stereotyping than high income households. For example, the third row of the table indicates that low income householders are much more likely than high income householders to agree with the statement: 'It is better for everyone involved if the man earns the money and the

18 Dougherty (2005) found that the college wage premium is higher for women than men in the US, and it has been higher for some time. However, this is generally not the case in Australia. Results from Kee (2006) suggested that females obtained higher returns from lower qualifications. The only exception is observed in the private sector, where returns to higher education were larger for women at the top of the conditional wage distribution. 
woman takes care of the home and children.' This difference is highly statistically significant, as the last column of the table indicates.

Table 3: Attitudinal variables by household income level, 2005 (a)

\begin{tabular}{|c|c|c|c|c|}
\hline & $\begin{array}{c}\text { Low } \\
\text { income } \\
\text { household } \\
\text { (b) }\end{array}$ & $\begin{array}{c}\text { High } \\
\text { income } \\
\text { household } \\
\text { (c) }\end{array}$ & Difference & t-stat \\
\hline $\begin{array}{l}\text { Many working mothers seem to care more about being } \\
\text { successful at work than meeting the needs of their } \\
\text { children. }\end{array}$ & 4.00 & 3.18 & 0.82 & 13.10 \\
\hline $\begin{array}{l}\text { Mothers who don’t really need the money shouldn’t } \\
\text { work. }\end{array}$ & 4.44 & 3.02 & 1.42 & 19.54 \\
\hline $\begin{array}{l}\text { It is better for everyone involved if the man earns the } \\
\text { money and the woman takes care of the home and } \\
\text { children. }\end{array}$ & 4.65 & 3.00 & 1.65 & 23.00 \\
\hline $\begin{array}{l}\text { A working mother can establish just as good a } \\
\text { relationship with her children as a mother who does } \\
\text { not work for pay. }\end{array}$ & 4.24 & 4.49 & -0.25 & -3.48 \\
\hline $\begin{array}{l}\text { It is not good for a relationship if the woman earns } \\
\text { more than the man. }\end{array}$ & 3.36 & 2.25 & 1.11 & 17.44 \\
\hline $\begin{array}{l}\text { On the whole, men make better political leaders than } \\
\text { women do. }\end{array}$ & 3.29 & 2.60 & 0.69 & 9.40 \\
\hline $\begin{array}{l}\text { A pre-school child is likely to suffer if his/her mother } \\
\text { works full-time. }\end{array}$ & 4.57 & 3.64 & 0.93 & 12.90 \\
\hline
\end{tabular}

One can speculate that this gender stereotyping would have been more pronounced in earlier times before the feminist revolution. Given such gender stereotyping we might expect the Higher Education Contributions Scheme (HECS) - introduced in 1989 as a means of financing a large-scale expansion of the higher education system (see for example Chapman, 1988) - to boost female enrolments relative to male, ceteris paribus. HECS aimed to make higher education more accessible for individuals from poorer backgrounds and these poorer students were more likely to come from families with gender stereotyping as well as poor access to credit. However Figures 4 and 5 do not support this hypothesis. There was no jump in 1989 in the proportion of females enrolled. 


\section{Opening up new opportunities}

The feminist revolution also meant that careers that had once seemed the purlieu of men were now socially acceptable for women. There was a general reduction in pressure to conform to social norms of suitable gender behaviour. Consequently a better matching of abilities to degree subject of career could now occur. Once upon a time a bright woman wanting a career would most likely have considered the teaching profession. ${ }^{19}$ A woman with a talent for physics or engineering would have found it hard socially to follow her abilities, and would then have battled to find employment. However from the 1960s this was all changing. At the same time, the erosion of stereotyping also affected men, although the number of occupations from which they had been effectively disbarred (nursing and childcare) was far smaller.

Table 4 gives female proportions by field of study in Australian universities over the period 1984 to 2007. It is striking that, in 2007, there are still some subject areas that have low or very high female proportions. For example, engineering and surveying are only $15.5 \%$ female and architecture is $40.9 \%$. In contrast education is $74 \%$ female, health is $72.9 \%$ female and science $52 \%$. $^{20}$

\footnotetext{
${ }^{19}$ Leigh and Ryan (2008) analyse data on the academic aptitude of new teachers entering the teaching profession, a large occupational grouping, accounting for 2.7 percent of all employees. Between 1983 and 2003, the average percentile rank of those entering teacher education fell from 74 to 61 , while the average rank of new teachers fell from 70 to 62. They argue that the fall in average teacher pay, and the rise in pay differentials in non-teaching | occupations account for the decline in the academic aptitude of new teachers over the past two decades.

${ }^{20}$ For an interesting comparison with Canada, see Andres and Adamuti-Trache (2007: Table 1).
} 
Table 4: Proportion female by field of study, 1984-2007 (overseas \& domestic)

\begin{tabular}{|c|c|c|c|c|c|c|c|c|c|c|}
\hline & $\begin{array}{l}\text { Agricul } \\
\text { ture }\end{array}$ & $\begin{array}{l}\text { Archite } \\
\text { cture }\end{array}$ & Arts & $\begin{array}{l}\text { Econom } \\
\text { ics }\end{array}$ & $\begin{array}{l}\text { Educati } \\
\text { on }\end{array}$ & $\begin{array}{l}\text { Enginee } \\
\text { ring }\end{array}$ & Health & Law & Science & Vet \\
\hline 1984 & 0.279 & 0.207 & 0.637 & 0.295 & 0.659 & 0.046 & 0.535 & 0.401 & 0.355 & 0.436 \\
\hline 1985 & 0.289 & 0.214 & 0.640 & 0.305 & 0.657 & 0.049 & 0.552 & 0.412 & 0.359 & 0.464 \\
\hline 1986 & 0.305 & 0.231 & 0.647 & 0.321 & 0.656 & 0.052 & 0.594 & 0.424 & 0.362 & 0.492 \\
\hline 1987 & 0.308 & 0.249 & 0.651 & 0.338 & 0.668 & 0.056 & 0.629 & 0.433 & 0.369 & 0.491 \\
\hline 1988 & 0.305 & 0.303 & 0.664 & 0.347 & 0.692 & 0.067 & 0.663 & 0.411 & 0.364 & 0.484 \\
\hline 1989 & 0.311 & 0.306 & 0.668 & 0.365 & 0.704 & 0.078 & 0.687 & 0.416 & 0.366 & 0.493 \\
\hline 1990 & 0.321 & 0.322 & 0.678 & 0.391 & 0.720 & 0.089 & 0.707 & 0.437 & 0.378 & 0.512 \\
\hline 1991 & 0.330 & 0.334 & 0.680 & 0.407 & 0.724 & 0.101 & 0.722 & 0.452 & 0.388 & 0.525 \\
\hline 1992 & 0.327 & 0.337 & 0.679 & 0.418 & 0.727 & 0.108 & 0.739 & 0.463 & 0.394 & 0.529 \\
\hline 1993 & 0.341 & 0.343 & 0.679 & 0.426 & 0.727 & 0.118 & 0.745 & 0.465 & 0.400 & 0.540 \\
\hline 1994 & 0.353 & 0.339 & 0.677 & 0.432 & 0.727 & 0.125 & 0.745 & 0.478 & 0.402 & 0.559 \\
\hline 1995 & 0.360 & 0.342 & 0.680 & 0.437 & 0.728 & 0.131 & 0.744 & 0.481 & 0.407 & 0.567 \\
\hline 1996 & 0.376 & 0.345 & 0.682 & 0.448 & 0.729 & 0.134 & 0.740 & 0.487 & 0.415 & 0.588 \\
\hline 1997 & 0.386 & 0.346 & 0.685 & 0.461 & 0.736 & 0.138 & 0.740 & 0.502 & 0.419 & 0.607 \\
\hline 1998 & 0.392 & 0.362 & 0.684 & 0.469 & 0.740 & 0.141 & 0.735 & 0.517 & 0.410 & 0.622 \\
\hline 1999 & 0.403 & 0.363 & 0.686 & 0.478 & 0.743 & 0.144 & 0.736 & 0.527 & 0.409 & 0.634 \\
\hline 2000 & 0.411 & 0.365 & 0.688 & 0.486 & 0.749 & 0.148 & 0.741 & 0.545 & 0.408 & 0.656 \\
\hline 2001 & 0.458 & 0.388 & 0.658 & 0.499 & 0.754 & 0.161 & 0.726 & & 0.523 & \\
\hline 2002 & 0.460 & 0.394 & 0.652 & 0.500 & 0.741 & 0.159 & 0.729 & & 0.523 & \\
\hline 2003 & 0.466 & 0.399 & 0.651 & 0.497 & 0.742 & 0.157 & 0.730 & & 0.527 & \\
\hline 2004 & 0.476 & 0.408 & 0.651 & 0.493 & 0.737 & 0.155 & 0.730 & & 0.527 & \\
\hline 2005 & 0.492 & 0.407 & 0.648 & 0.488 & 0.736 & 0.154 & 0.730 & & 0.528 & \\
\hline 2006 & 0.500 & 0.411 & 0.644 & 0.486 & 0.733 & 0.154 & 0.729 & & 0.524 & \\
\hline 2007 & 0.505 & 0.409 & 0.641 & 0.485 & 0.740 & 0.155 & 0.729 & & 0.520 & \\
\hline
\end{tabular}

Source: DETYA (2000) and DEEWR (2001-2007).

(a) Full names of the field of study are: Agriculture- Agriculture and Animal Husbandry; Architecture- Architecture and Building; Arts- Arts, Humanities and Social Sciences; Economics- Business, Administration and Economics; Engineering- Engineering and Surveying; Law- Law and Legal studies; Vet- Veterinary Science. (b) Figures for years from 1985 to 1993 progressively include State-funded basic nursing students transferred from hospitals. (c) The field of study classification changed in 1987. The main effects were to transfer certain courses from Science to Health and from Business to Law, and hence to reduce Science and Business enrolments and to increase Health and Law enrolments. (d) Data from 1997 onwards were compiled in a different way to data for prior years to take into account the coding of Combined Courses to two fields of study. As a consequence, the total for some broad fields of study show larger increases than would be the case if data for only one field were to be counted. Counting both fields of study for Combined Courses means that the totals for each year may be less than the sum of all Broad Fields of Study. (e) Figures for 2000 to 2007 are extracted from the aggregated student datasets. These datasets are from the Department of Education, Employer and Workplace Relations (DEEWR) website. http://www.dest.gov.au/sectors/higher_education/publications_resources/statistics/higher_education_statistics_colle ction.htm (f) Note that from 2001 onwards, a new Field of education classification (Australian Standard Classification of Education-ASCED) was introduced, replacing the less detailed field of study classification. Hence data before and after 2000 might not be directly comparable. (g) Prior to 2001 annual enrolments only counted students undertaking units of study at 31 March, whereas from 2001 onwards, all students undertaking study at any time of the year were counted. This means that there is a break between series before and after 2001. 
Are there gender differences in secondary school achievement?

Is there any evidence of gender differences in secondary school achievement that might feed into gender gaps in higher education enrolment? To answer this question, Booth and Kee (2009) looked at the score differences in reading, numeracy and science between boys and girls from 1975 to 2006, using information extracted from multiple sources. These studies indicated that in Australia girls are doing better than boys at reading, as well as boys at science, and slightly worse than boys at numeracy. There is thus no compelling reason to think that, on average, poor performance by either gender at secondary school should feed into lower university enrolment rates. Nonetheless, we believe that it is likely that the gender gap in higher education in favour of women will persist into the future. This is because of the continuing the growth of white collar and service sector jobs and the enthusiasm of women to engage in work outside the home. ${ }^{21}$ Moreover house prices are also increasing and this trend seems likely to continue, making it hard for the average Australian family to service a mortgage on only one income.

\section{Conclusion}

According to the 1911 Census, the proportion of females receiving educational instruction at university was around 22\%, growing to $29 \%$ in 1921 . While the data series are not strictly comparable owing to changes in educational definition over time, the proportion of female university enrolments in 1939 was just 28\%. By 1952 it had dropped further to under 20\%, due in part to the easy access into universities for the returning war-veterans. From the early 1950s, the university-educated gender gap began to reduce, probably due to the moving on of the cohort of returned servicemen, and then later in response to women's changing expectations of future labour-force participation, fertility and age at first marriage. Technological breakthroughs in household technology and in contraception began to remove constraints to female choice.

At the same time innovations in market production led to substitution from unskilled brawn to more skilled brain, thereby increasing the demand for skilled labour and raising relative skilled wages. Women, now more easily able to postpone family formation, began to find it worthwhile to invest in higher education. Simultaneously gender stereotypes became eroded. The civil rights

\footnotetext{
${ }^{21}$ There remain - and are likely to remain in the future - a number of traditionally male occupations requiring postschool apprenticeship rather than university training. Service sector work, in contrast, is typically entered via a university degree and this may help explain why there are more women at university than men.
} 
movement demanded equal rights for women and blacks, raising awareness of discrimination. The removal of the marriage bar and equal pay cases codified this. As women experienced improved career opportunities, they enjoyed a higher return to tertiary education and so invested more. At around the same time, abortion on demand and divorce without blame were legalised. Women and men could no longer expect their first marriage to last and therefore some women were likely to make educational investments to insure against the risk of income loss. Innovations in the funding of higher education in 1989 widened access to children from lower income families, although the evidence does not suggest that this assisted women more than men. By 1987, less than a century after Federation, Australian women were more likely than men to be enrolled at university. However, these aggregate figures disguise considerable heterogeneity across fields of study. There are significant fields - such as engineering and surveying - where women remain in the minority, and other fields - education and health where they are in the overwhelming majority. That girls are now performing at least as well as boys in secondary education suggests the higher education gender gap is likely to continue. 


\section{References}

Andres, L. and M. Adamuti-Trache (2007) You've Come a Long Way, Baby? Persistent gender Inequality in Univesity Enrolment and Completion in Canada, 1979-2004. Canadian Public Policy, 28 (1), 94-116.

Austin, A.G. (1977) Australian Education 1788-1900. Church, State and Public Education in Colonial Australia (Melbourne Australia: Pitman Publishing).

Australian Bureau of Statistics (1911), Census of the Commonwealth of Australia, microfiche, (ABS, Canberra).

Australian Bureau of Statistics (1921), Census of the Commonwealth of Australia, microfiche, (ABS, Canberra).

Australian Bureau of Statistics, (1901-1923), 1901-1923 Year Book Australia, Cat. No. 1301.0, (ABS, Canberra).

Australian Bureau of Statistics (1906-1974), 1906-1974 Year Book Australia, Cat. No. 1301.0, (ABS, Canberra).

Australian Bureau of Statistics (1941-1974), 1941-1974 Year Book Australia, Cat. No. 1301.0, (ABS, Canberra).

Australian Bureau of Statistics (1997), Australian Social Trends, Cat. No. 4102.0, [Viewed 27 March 2009]. Available from URL: http://www.abs.gov.au/AUSSTATS/abs@.nsf/2f762f95845417aeca25706c00834efa/a8d 1bea8a2ff1b33ca2570ec001b0dc3!OpenDocument.

Australian Bureau of Statistics (2004), Australian Social Trends, Cat. No. 4102.0, (ABS, Canberra), p.p. 171.

Australian Bureau of Statistics (2006), Australian Historical Population Statistics, Cat. No. 3105.0.65.001, Table 2 and Table 38. [Viewed 20 Feb 2009.] Available from URL: http://www.abs.gov.au/AUSSTATS/abs@.nsf/DetailsPage/3105.0.65.0012006?OpenDo cument.

Australian Bureau of Statistics (2007a), Births, Australia, Cat. No. 3301.0, (ABS, Canberra).

Australian Bureau of Statistics (2007b), Divorces, Australia, Cat. No. 3307.0.55.001, (ABS, Canberra).

Australian Bureau of Statistics (2008a), Employee Earnings, Benefits and Trade Union Membership, Cat. No. 6310.0, (ABS, Canberra).

Australian Bureau of Statistics (2008b), Education and Work, Cat. No. 6227.0, (ABS, Canberra). 
Australian Bureau of Statistics (2009), Labour Force, Australia, Detailed, Cat. No. 6291.0.55.001, [Viewed 1 March 2009]. Available from URL: http://www.abs.gov.au/AUSSTATS/abs@.nsf/DetailsPage/6291.0.55.001May\%202009? OpenDocument.

Barcan, A. (1980), A History of Australian Education. Melbourne: Oxford University Press.

Baron, JD and D Cobb-Clark (2008). Occupational Segregation and the Gender Wage Gap in Private- and Public-Sector Employment: A Distributional Analysis. IZA Discussion Paper No 3562. Forthcoming 2010, Economic Record.

Booth, AL and HJ Kee (2009) The University Gender Gap in Australia: A Long-run Perspective. Canberra: CEPR Discussion Paper No 610.

Borland, J (1999). Earnings Inequality in Australia: Changes, Causes and Consequences. Economic Record, 75, 177-202.

Butlin, M. (1977). A Preliminary Annual Database 1900/01 to 1973/74, RBA Research Discussion Paper No. 7701, May.

Carmichael, G. (1990) A Cohort Analysis of Marriage and Informal Cohabitation among Australian Men. Australian and New Zealand Journal of Sociology, 27 (1), March.

Carmichael, G. (1995) Consensual partnering in the more developed countries, Journal of the Australian Population Association, 12(1), May.

Chapman, B. (1988). 'The Higher Education Contributions Scheme' in D Jones, VL Meek and J Anwyl, eds. Alternative Funding Strategies. (Centre for the Study of Higher Education, University of Melbourne), pp33-44.

Coles, M.G. and Francesconi, M. (2007) On the Emergence of Toyboys: Equilibrium Matching with Ageing and Uncertain Careers, IZA Discussion Paper No. 2612 (Institute for the Study of Labor).

Department of Education, Training and Youth Affairs (DETYA) (2000), Higher Education Students Time Series Table - Selected Higher Education Statistics, (Commonwealth of Australia, Canberra).

Department of Education, Employment and Workplace Relations (DEEWR) (2001-2007), Students: Selected Higher Education Statistic. [Accessed 20 March 2009]. Available from http://www.dest.gov.au/sectors/higher_education/publications_resources/statistics/public ations_higher_education_statistics_collections.htm.

Dougherty, C. (2005) Why are Returns to Schooling Higher for Women than for Men? Journal of Human Resources, 40(4): 969-88.

Eastough K and PW Miller (2004) The Gender Wage Gap in Paid- and Self-Employment in Australia, Australian Economic Papers, 43 (3): 257-276, September. 
Goldin, C. and Katz, L.F. (2008) The Race between Education and Technology. Cambridge, Ma: Harvard University Press.

Graff, H. J. (1979) The Literacy Myth: Cultural Integration and Social Structure in the Nineteenth Century Edition: reprint, (Transaction Publishers, 1991). Originally published: New York: Academic Press, c1979.

Hastings, G. (2008) An Outline of the Historical Development of Commonwealth Student Financial Programs in Australia (1942 - 2008). Appendix 1 in the National Union of Students’ Higher Education Review Submission, July 2008.

Headey, B; Warren, D; Harding, G. (2006). Families, Incomes and Jobs: A statistical report of the HILDA survey. Commonwealth of Australia. 3306.0.55.001 Marriages, Australia, 2004. Canberra: Australian Bureau of Statistics.

Keating, M. (1973) The Australian Workforce 1910-11 to 1960-61, The Australian National University, Canberra.

Kee, H.J. (2006) Glass Ceiling or Sticky Floor? Exploring the Australian Gender Pay Gap. The Economic Record, 82(259): 408-427.

Leigh, A and C Ryan (2008) How and Why has Teacher Quality Changed in Australia? Australian Economic Review, 41(2): 141-159

OECD (2008). Tertiary Education for the Knowledge Society: Thematic Review of Tertiary Education, (OECD, Paris).

Reserve Bank of Australia, Historical Statistics, Table 4.15, column under 'Total rate(c)'.

Reserve Bank of Australia Bulletin Statistics (monthly data). Table G07, Title: Labour Force, column under 'Unemployment rate'. For consistency data for August is used, Web link: (http://www.rba.gov.au/Statistics/Bulletin/G07hist.xls). [Viewed 24 June, 2009].

Sawer, M. (1997) Removal of the Commonwealth Marriage Bar: A Documentary History, University of Canberra: Centre for Research in Public Sector Management.

Short, C. (1986), Equal Pay-What Happened? Journal of Industrial Relations, 28, 315-335.

Weston, R. and Qu, L. (2006) Trends in couple dissolution, AIFS Family Relationships Quarterly, 2: 9-12, (Australian Institute of Family Studies, Melbourne).

Withers, G, AM Endry and TM Perry, (1987). 'Labour'. Chapter 9 pp 145-165, in Vamplew, W. (1987) (ed) Australians, Historical Statistics. Sydney, Australia: Fairfax, Syme \& Weldon Associates. 


\section{Appendix A Tables and Graphs}

Table A.1: Enrolled in a course of study, by age by gender, 1998-2008 ('000s)

\begin{tabular}{lllllllll}
\hline & Males & & & \multicolumn{7}{c}{ Females } \\
& $\mathbf{2 5 - 3 4}$ & $\mathbf{3 5 - 4 4}$ & $\mathbf{4 5 - 5 4}$ & $\mathbf{5 5 - 6 4}$ & $\mathbf{2 5 - 3 4}$ & $\mathbf{3 5 - 4 4}$ & $\mathbf{4 5 - 5 4}$ & $\mathbf{5 5 - 6 4}$ \\
\hline 1998 & 151.2 & 90.2 & 38.3 & 9.8 & 158.3 & 109.6 & 60.8 & 10.8 \\
2000 & 157.5 & 84.2 & 42.6 & 8.3 & 170.3 & 120.4 & 63.3 & 12.4 \\
2002 & 186.2 & 96 & 46.9 & 9.4 & 182.8 & 128.1 & 76.5 & 15.4 \\
2004 & 174.6 & 92.8 & 46.9 & 18.6 & 200.8 & 144 & 85.4 & 17.6 \\
2006 & 158.3 & 81.9 & 41.3 & 14.8 & 183.1 & 134.9 & 84.6 & 21.9 \\
2007 & 161.7 & 93.5 & 50.6 & 14.7 & 210.9 & 133.4 & 87.3 & 25.4 \\
2008 & 184.2 & 97 & 53.1 & 17.1 & 194.4 & 131.4 & 91.1 & 26.7 \\
\hline
\end{tabular}

Source: ABS 2008b.

Figure A.1: Australian Unemployment Rate, 1901-2007

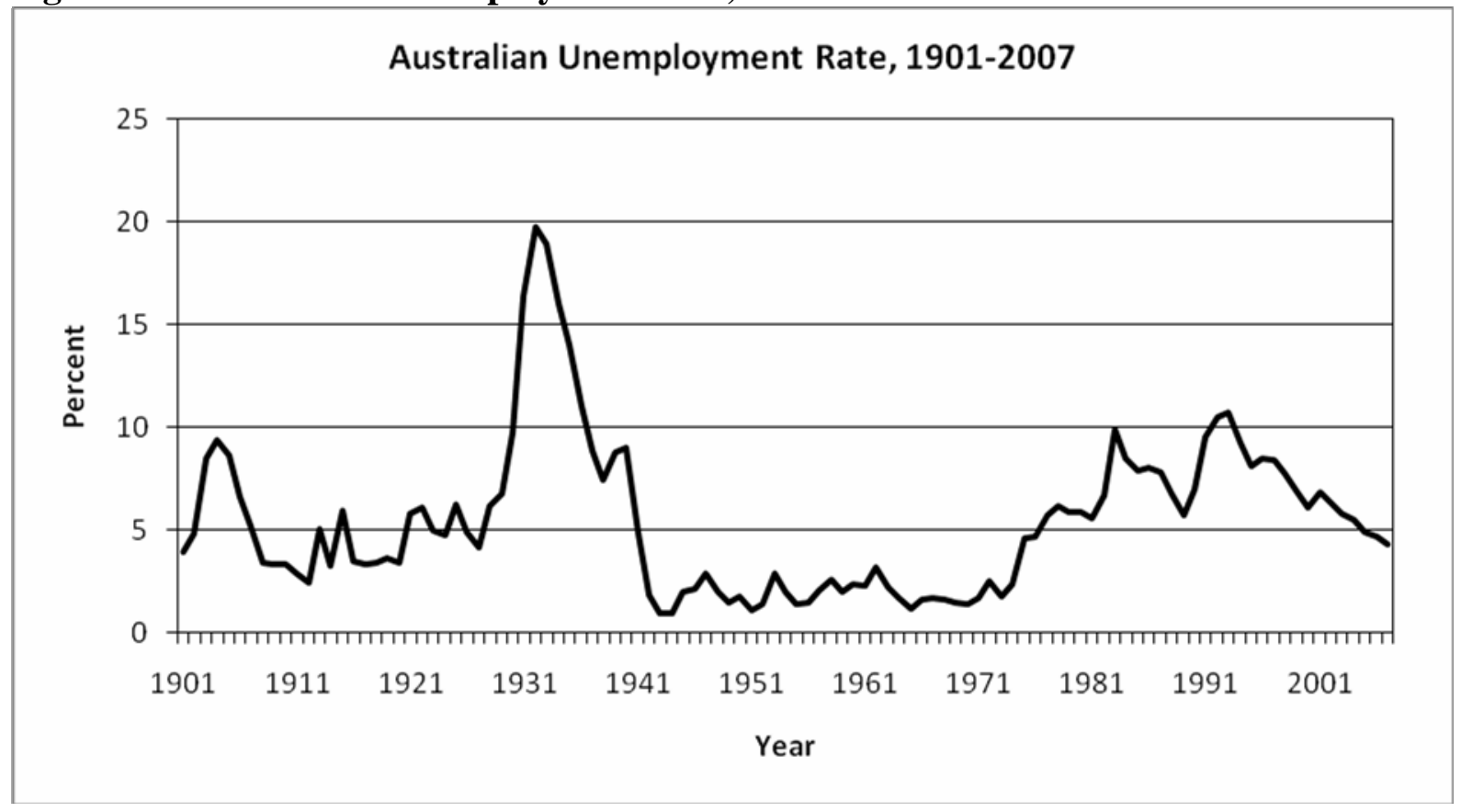

Average unemployed per year as a percentage of total workforce.

Source: a) 1901 to 1964 is from Vamplew (1987), Table: LAB 86-97, column 97, p. 152. The original source of this series is Butlin, M. (1977). "A Preliminary Annual Database 1900/01 to 1973/74," RBA Research Discussion Paper No. 7701, May. b) 1965 to 1996 is from RBA historical statistics, Table 4.15, column under 'Total rate(c)'. Originally Data are from the ABS Labour Force Survey, August data, Web link:

(http://www.rba.gov.au/Statistics/OP8ExcelFiles/4-15.xls). c) 1997 to 2007 is from RBA Bulletin Statistics (monthly data), Table G07, Title: Labour Force, column under 'Unemployment rate'. For consistency data for August is used, Web link: (http://www.rba.gov.au/Statistics/Bulletin/G07hist.xls). 
Figure A.2: Labour force participation rates by gender, 1978-2008.

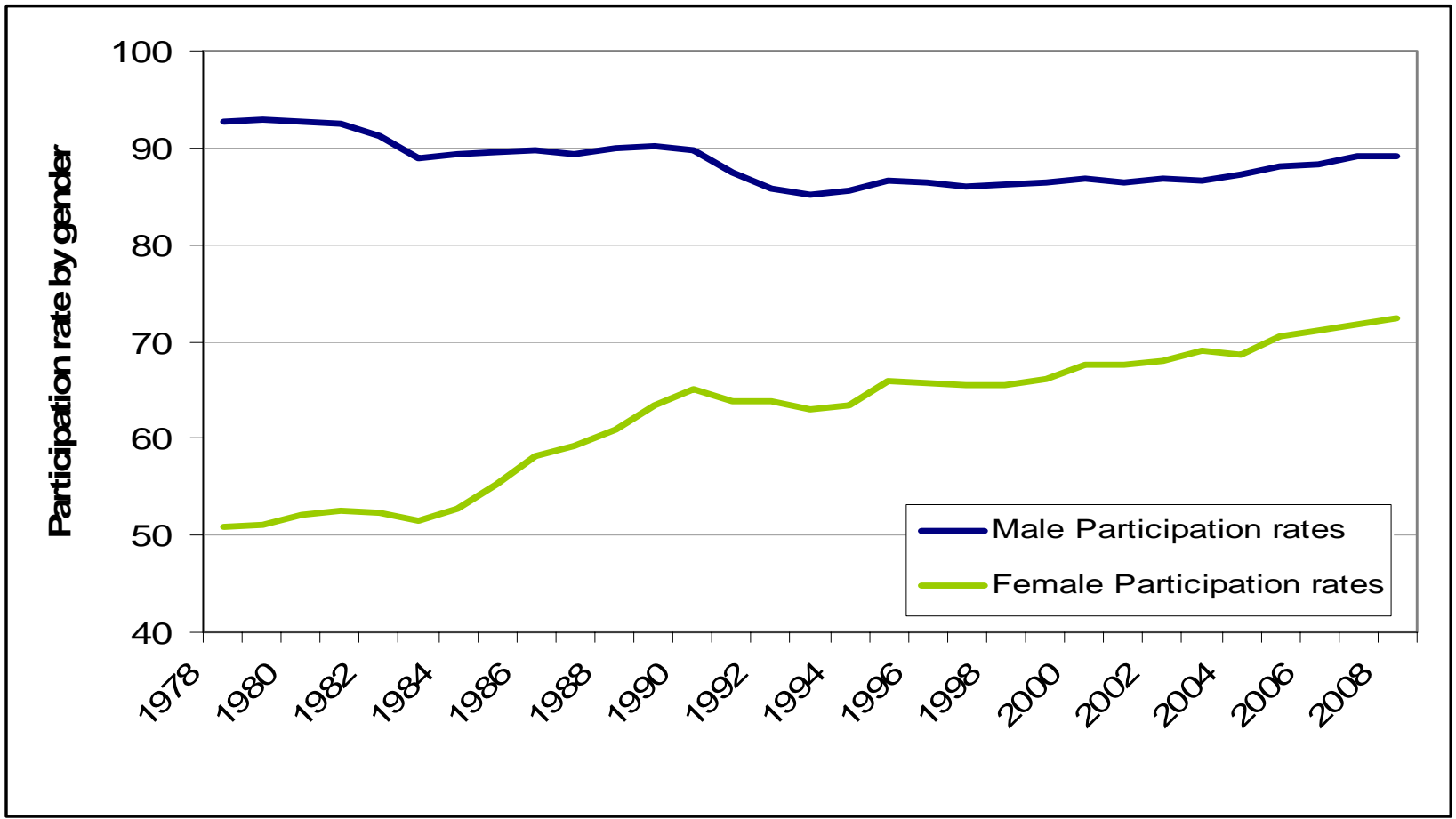

Source: ABS 2009.

Note: Included only males and females between 30 and 50 years old.

Figure A.3: Nominal mean weekly earnings by gender, 1978-2007.

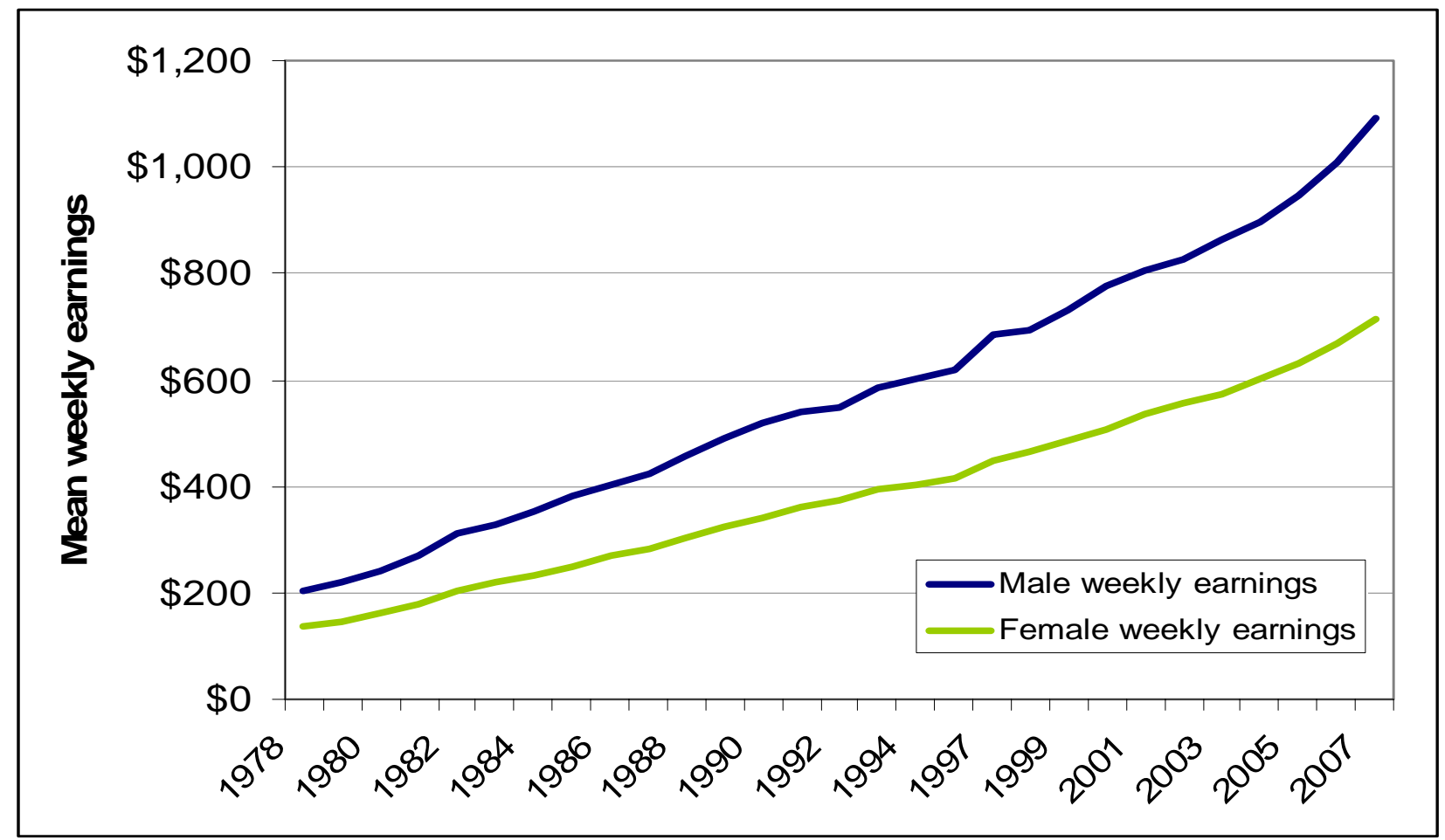

Source: ABS 2008a.

Note: (i) The survey was not run in 1996. (ii) From 2007, employees were asked to include salary sacrifice in their estimates of earnings. (iii) All data are original series. 
Figure A.4: Median age of mother, first nuptial confinement, 1966-2006

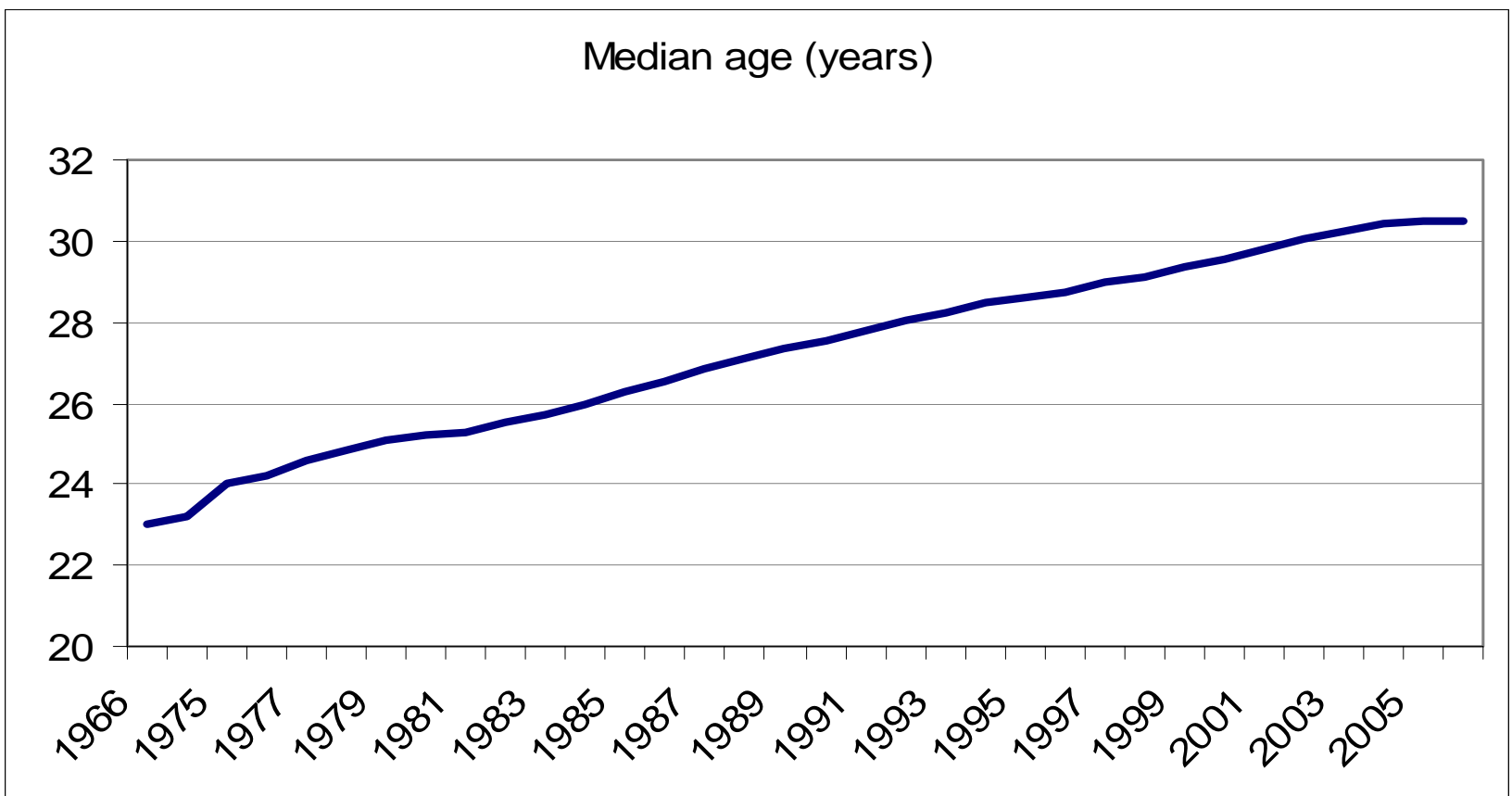

Source: ABS 2006 and ABS 2007a.

Figure A.5: First nuptial confinement by age groups, 1966-2006

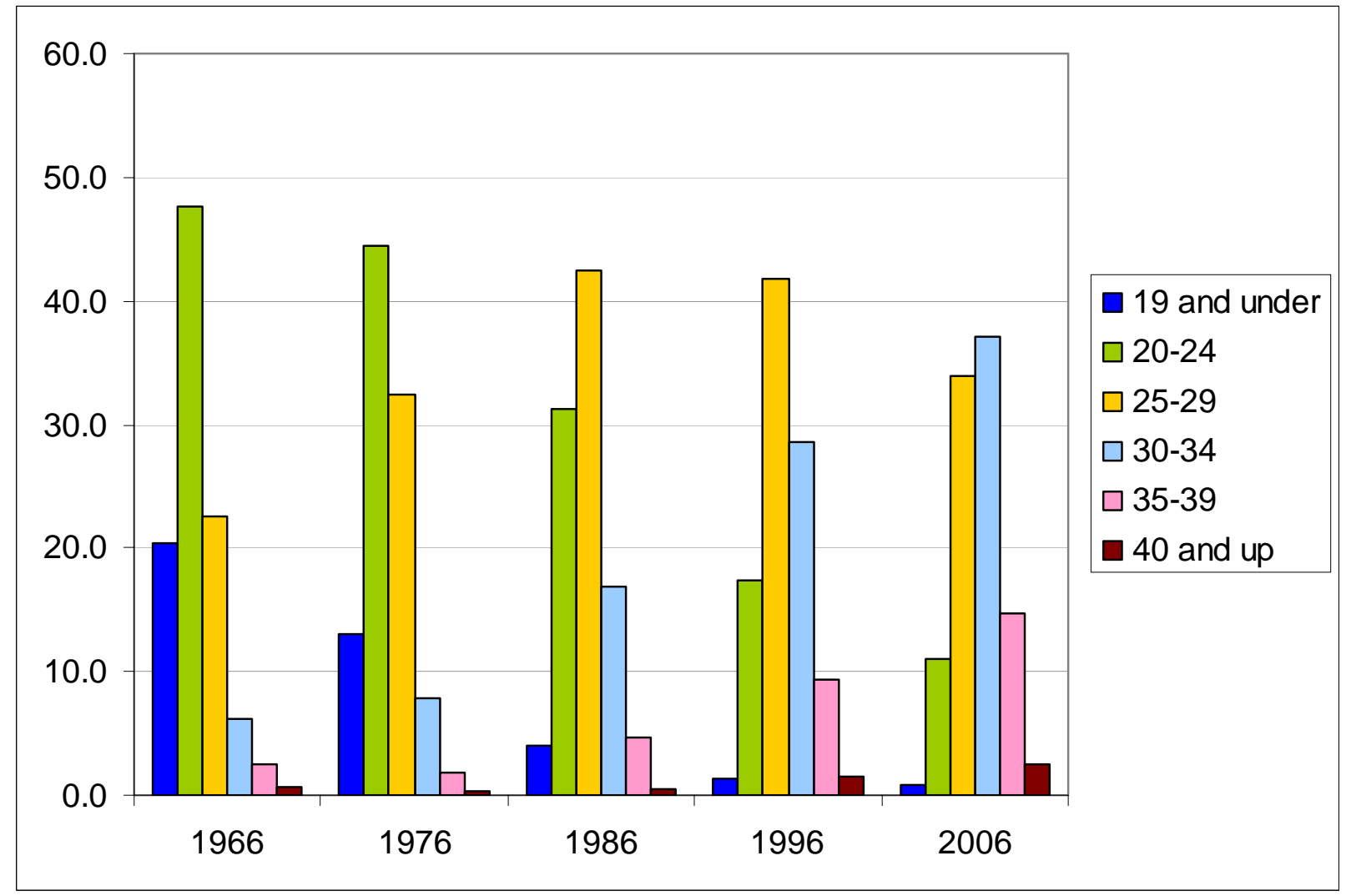

Source: ABS 2007a. 